\title{
KARAKTERISTIK KETINGGIAN DASAR AWAN YANG DIUKUR DENGAN SENSOR INFRA MERAH RADIOMETER PADA PUNCAK MUSIM HUJAN DI JABODETABEK.
}

\author{
Characteristic of Cloud Base Height Measured by Infrared Pyrometer of \\ Microwave Radiometer During the Rainy Season in Jabodetabek Area
}

\author{
Findy Renggono ${ }^{1 *}$ \\ 1) Balai Besar Teknologi Modifikasi Cuaca - Badan Pengkajian dan Penerapan Teknologi, Gedung Ir. \\ Mohammad Soebagio, GEOSTECH (820), Kawasan PUSPIPTEK, Serpong, Tangerang Selatan \\ *E-mail: findy.renggono@bppt.go.id
}

\begin{abstract}
Intisari
Informasi mengenai tinggi dasar awan penting bagi penelitian atmosfer dan juga sebagai masukan bagi pemodelan cuaca. Pada kegiatan modifikasi cuaca, informasi ini juga sangat penting dalam menentukan awan yang akan disemai. Dalam tulisan ini, pengukuran tinggi dasar awan dilakukan dengan menggunakan sensor infra merah yang terpasang pada radiometer. Sensor infra merah ini akan mengukur suhu dasar awan yang kemudian dapat diketahui ketinggiannya dengan melihat temperatur lapse rate. Hasil pengukuran dibandingkan dengan hasil pengamatan awan oleh micro rain radar yang terletak di lokasi yang sama. Hasil pengukuran dari kedua peralatan ini menunjukkan kesesuaian antara kemunculan awan pada micro rain radar yang ditunjukkan dengan struktur vertikal awan dengan hasil pengamatan dengan IRT dari radiometer. Pengamatan selama puncak musim hujan di Jabodetabek (Januari - Maret 2019) menunjukan adanya pola harian yang cukup jelas.
\end{abstract}

Kata Kunci: Dasar Awan, Radiometer, IRT.

\begin{abstract}
Information on cloud properties is important for atmospheric research and as well as for weather modeling. In weather modification, this information is very important for cloud seeding strategy. The observation of cloud base height is carried out using infrared sensors mounted on a radiometer. These infrared thermometer sensors are capable of detecting the cloud base temperature, the cloud base height is obtained by looking at the temperature lapse rate retrieved from radiometer observation. The results were compared with the cloud observation by micro rain radar which is located at the same location. The comparison results of these two instruments show that the consistency of cloud detection was good. Based on the observation during the peak of the rainy season in Jabodetabek (January-March 2019), it is shown a fairly clear daily pattern.
\end{abstract}

Keywords: Cloud Base, radiometer, IRT.

\section{PENDAHULUAN}

Informasi mengenai parameter awan sangat penting bagi penelitian atmosfer, karena proses di permukaan seperti dinamika atmosfer, siklus hidrologi, dan kesetimbangan radiasi sangat berhubungan erat dengan awan. Bagi Teknologi Modifikasi Cuaca (TMC), informasi tentang tinggi dasar dan puncak awan sangat dibutuhkan dalam rangka mencari awan yang cocok untuk disemai. Pengamatan parameter awan secara berkelanjutan juga berguna bagi penelitian tentang perubahan iklim.

Saat ini untuk menentukan tinggi puncak awan dapat dengan mudah dilakukan dengan menggunakan data satelit, namun untuk memperoleh informasi ketinggian dasar awan cukup sulit untuk dilakukan. Pengamatan tinggi dasar awan dapat dilakukan dengan berbagai macam cara, dari mulai cara yang paling sederhana hingga menggunakan peralatan canggih seperti ceilometer, lidar, radar dan lainlain. Masing-masing instrumen mempunyai kelebihan dan kekurangan masing-masing. Cara yang biasa dilakukan adalah dengan menentukan LCL (Lifting Condensation Level) dari data temperatur permukaan dan dew point yang kemudian dimasukan ke grafik skewT-log $p$ (Stackpole, 1967). Pada tahun 2002, Craven et al membandingkan pengukuran dasar awan dengan metoda LCL ini dengan menggunakan beberapa teknik. Forsythe (2000) mencoba 
mengukur tinggi dasar awan dengan data satelit dibantu dengan laporan pengukuran tinggi dasar awan dari beberapa stasiun pengamat.

Suhu dasar awan dapat diukur dengan menggunakan termometer infra merah (Mims III et al, 2011). Dari pengukuran suhu dasar awan tersebut dapat diperoleh tinggi dasar awan jika diketahui temperatur lapse rate. Pengukuran langsung profil temperatur biasanya menggunakan balon yang diperlengkapi sensor (radiosonde), akan tetapi saat ini dapat juga menggunakan microwave radiometer untuk mengetahui profil temperatur. Wang et al (2018) membandingkan pengukuran dasar awan dengan menggunakan infra red dan radar awan. Sedangkan penelitian lain menggunakan radiometer dan MRR untuk mempelajari kemunculan LWC di atmosfer karena kedua alat tersebut masing-masing mempunyai karakteristik pengukuran LWC yang berbeda sehingga dapat meningkatkan hasil pengukuran (Yang et al, 2013).

Pengukuran dasar awan dengan termometer infra merah (IRT) di wilayah tropis pada musim hujan belum pernah dilakukan. Tujuan dari tulisan ini adalah untuk memeriksa kemampuan IRT dalam mengukur ketinggian dasar awan dan mencari karakteristik kemunculan awan pada musim hujan di Serpong berdasarkan ketinggian dasar awannya.

\section{METODE}

\subsection{Pengamatan Hujan di Serpong}

Wilayah di DKI Jakarta memiliki pola hujan monsun, yaitu mempunyai satu puncak musim hujan dan musim kering. Pola musim hujankering terlihat jelas seperti yang digambarkan pada gambar 1 .

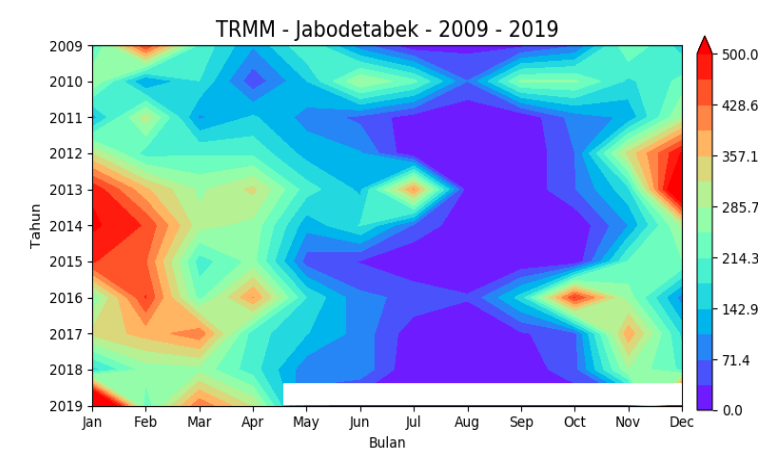

Gambar 1. Akumulasi hujan bulanan di Jabodetabek bulan Januari 2009 - April 2019.

Gambar ini adalah akumulasi curah hujan bulanan dari data TRMM bulan Januari 2009 April 2019. Perhitungan curah hujan untuk wilayah DKI dengan data TRMM ini sesuai dengan metode yang dilakukan oleh Syaifullah (2014). Pada gambar ini terlihat bahwa musim hujan muncul pada bulan November sampai April, dan puncaknya sekitar bulan Januari-Februari.
Pada bulan Februari 2019 agak lebih rendah dari rata-ratanya namun total akumulasi curah hujannya masih di atas $200 \mathrm{~mm}$.

Pengamatan hujan dengan Disdrometer yang dipasang di Puspiptek Serpong (sekitar 30km Barat Daya Jakarta, 6.359LS, 106.673BT) menunjukkan pola yang sama. Hujan pada bulan Desember sampai April di wilayah ini juga cukup tinggi. Hasil pengukuran curah hujan harian dengan disdrometer untuk bulan Januari-Maret 2019 dapat dilihat pada gambar 2. Pada gambar ini terlihat bahwa curah hujan harian berkisar antara 0-134 mm, dengan total hujan bulanan adalah masing-masing 346.8, 281.3, dan 171.3 $\mathrm{mm}$ untuk bulan Januari, Februari dan Maret 2019. Rata-rata curah hujan harian hanya berkisar di bawah $15 \mathrm{~mm} /$ hari, namun terlihat ada beberapa yang mempunyai curah hujan harian di atas $50 \mathrm{~mm} /$ hari, yaitu tanggal 9 Januari, 21 Januari, 19 Februari, dan 4 Maret 2019.

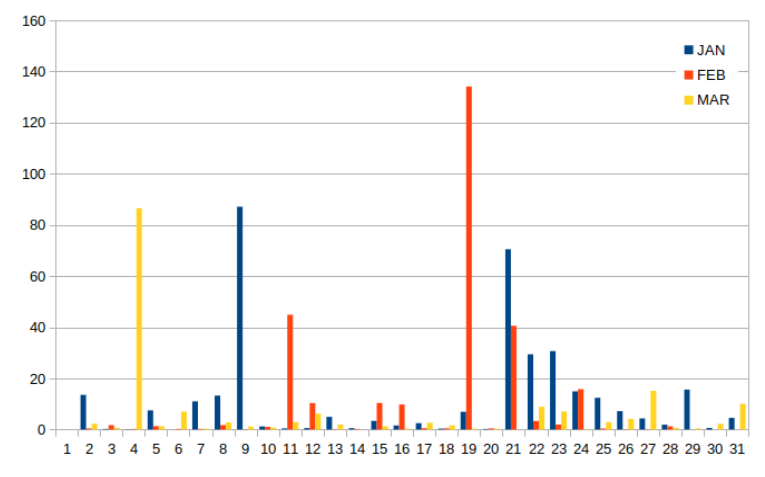

Gambar 2. Curah hujan harian di Serpong bulan Januari (biru), Februari (merah) dan Maret (kuning) 2019 berdasarkan pengamatan dengan disdrometer.

\subsection{Pengamatan dengan Radiometer}

Radiometer adalah sebuah microwave radiometer yang dapat mengukur profil tekanan, temperatur, kelembapan relatif dan kandungan uap air sampai ketinggian sekitar $10 \mathrm{~km}$ pada kondisi cerah maupun berawan secara berkelanjutan. Radiometer yang digunakan pada penelitian ini adalah Radiometrics tipe MP3000A. Hasil studi sebelumnya menunjukkan bahwa perbandingan hasil pengukuran profil temperatur antara radiometer dengan radiosonde menunjukkan kesesuaian hasil yang cukup baik (Athoillah et al, 2016).

Radiometer ini juga dilengkapi dengan sensor pengukur parameter meteorologi permukaan, seperti temperatur permukaan, kelembapan udara permukaan, dan tekanan permukaan yang digunakan untuk menentukan profil temperature dan $\mathrm{RH}$. Selain itu juga ada sensor hujan dan sensor infra merah (Infra Red Thermometer, IRT). Sensor IRT yang dipasang menghadap ke atas ini digunakan untuk mendeteksi keberadaan awan dan mengukur temperatur dasar awannya. Sensor IRT yang digunakan adalah KT19.85 buatan Heitronics. 
Pengamatan udara atas dengan Radiometer di Serpong sudah dimulai dari awal tahun 2016, namun tidak dilakukan secara terus menerus. Jadwal kegiatan pengamatan udara atas dengan radiosonde dapat dilihat pada Tabel 1.

Tabel 1. Pengamatan dengan Radiosonde.

\begin{tabular}{|c|c|c|}
\hline No & Periode & Lokasi \\
\hline 1 & 17 Jan 2016-16 Feb 2016 & Bogor \\
\hline 2 & 3 Mar 2016-9 Mei 2016 & Serpong \\
\hline 3 & 8 Des 2016-6 Jun 2017 & Serpong \\
\hline 4 & 9 Okt 2018 - 17 Nov 2018 & Surabaya \\
\hline 5 & 8 Jan 2019-30 Mei 2019 & Serpong \\
\hline
\end{tabular}

\subsection{Pengukuran Tinggi Dasar Awan}

Pengukuran tinggi dasar awan dilakukan dengan menggunakan sensor IRT yang terpasang pada radiometer. Jika ada awan, IRT akan mengukur temperatur dasar awan. Dengan mengetahui suhunya, dapat diketahui kerapatan uap air pada dasar awan, dan dikombinasikan dengan profil temperatur akan diperoleh tinggi dasar awan. Hasil pengukuran tinggi dasar awan ini akan dibandingkan dengan hasil pengukuran awan dengan Micro Rain Radar (MRR) yang dipasang di lokasi yang sama dengan radiometer.

MRR merupakan sebuah radar hujan yang beroperasi pada frekuensi $24 \mathrm{GHz}$ (panjang gelombang $=1.25 \mathrm{~cm}$ ). Radar dengan antena parabola berdiameter $60 \mathrm{~cm}$ yang diarahkan tegak lurus ke atas ini dapat mengukur distribusi butir hujan dari $15 \mathrm{~m}$ sampai lebih dari $6000 \mathrm{~m}$ setiap menit secara kontinyu. Dari perhitungan distribusi butir hujan dapat diperoleh curah hujan, LWC dan kecepatan jatuh butir hujan untuk 30 level ketinggian. Profil reflektivitas dan profil kecepatan jatuh dari MRR ini mampu menggambarkan struktur vertikal dari kejadian hujan. Dengan menggunakan algoritma klasifikasi awan yang dikembangkan William et al (1995) yang telah disesuaikan, kemunculan awan hujan yang teramati oleh MRR dapat dipisahkan menjadi dua jenis awan hujan, yaitu awan konvektif dan stratiform (Renggono, 2017) dengan syarat hujan tidak terlalu deras. Peters et al (2002) menyebutkan bahwa pengamatan hujan dengan MRR ini juga mempunyai korelasi yang bagus dengan pengamatan menggunakan penakar hujan konvensional.

\section{HASIL DAN PEMBAHASAN}

\subsection{Pengamatan Hujan 3.1.1. Kejadian Hujan tanggal Februari 2019}

Pengamatan hujan dengan disdrometer pada bulan Januari-Maret 2019 menunjukkan bahwa curah hujan harian bervariasi antara 0 -
$134 \mathrm{~mm}$ seperti yang ditunjukkan gambar 2 . Walaupun akumulasi curah hujan bulan Februari 2019 bukan yang paling tinggi, namun curah hujan harian tertinggi terlihat muncul pada bulan ini, yaitu tanggal 19 Februari 2019. Pada hari itu hujan hanya terjadi sekitar 90 menit namun menghasilkan curah hujan yang cukup tinggi (gambar 3). Hujan terlihat mulai muncul sekitar pukul 6.40 dan beberapa menit kemudian curah hujannya langsung mencapai di atas 150 $\mathrm{mm} / \mathrm{jam}$ dan mulai menurun pada pukul 07.45 hingga pada pukul 08.10 hujan berhenti. Sebagai catatan, semua penulisan waktu dalam tulisan ini berdasarkan standard UTC.

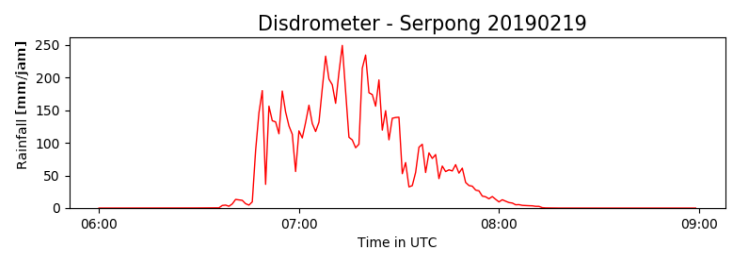

Gambar 3. Curah hujan yang terukur oleh

Disdrometer di Serpong tanggal 19 Februari 2019.

Reflektivitas dari MRR juga menunjukkan adanya kejadian hujan antara pukul $06.40-08.15$ dengan terdeteksinya reflektivitas yang tinggi dan adanya pergerakan jatuh butir hujan selama periode tersebut seperti yang ditunjukkan pada gambar 4. Pada pengukuran ini MRR diatur agar dapat mengamati parameter hujan dari $250 \mathrm{~m}$ sampai $7750 \mathrm{~m}$ setiap $250 \mathrm{~m}$.

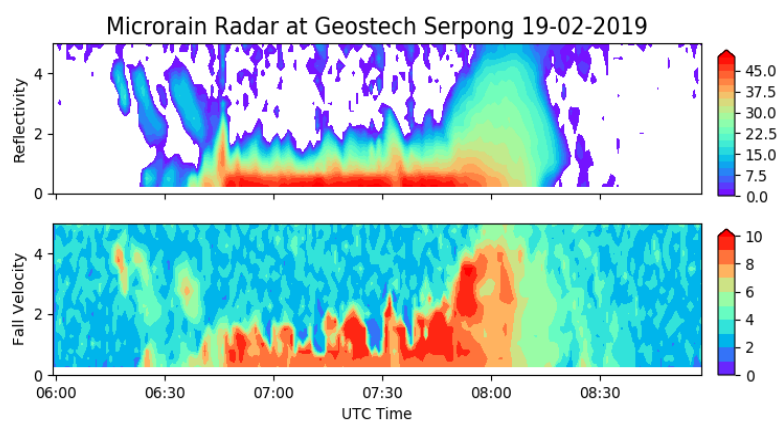

Gambar 4. Reflektivitas (atas) dan Kecepatan jatuh butir hujan (bawah) pada kejadian hujan tanggal 19 Februari 2019 yang diamati oleh MRR.

Pada pukul 06.15 - 06.40, hujan belum mencapai permukaan, namun pada pengamatan dengan MRR terlihat reflektivitas sebesar 2-4 $\mathrm{dBZ}$ bergerak turun dari ketinggian $4 \mathrm{~km}$ dengan kecepatan sekitar 6-10 m/detik (gambar 4). Walaupun di permukaan belum terdeteksi adanya hujan, akan tetapi keberadaan awan yang mengandung cukup uap air sudah dapat terlihat dengan jelas.

Antara pukul $6.40 \quad-7.50$ terlihat reflektivitas yang kuat ( $>45 \mathrm{dBZ}$ ) sampai ketinggian kurang dari $1 \mathrm{~km}$ setelah itu melemah sampai sekitar ketinggian $2 \mathrm{~km}$. Kondisi ini adalah tahap dimana awan dalam keadaan 
matang (mature), yang dicirikan dengan adanya downdraft, hujan deras dan reflektivitas yang tinggi sampai lebih dari $4.5 \mathrm{~km}$. Walaupun ciri-ciri sebagai hujan konvektif sudah sesuai, tapi reflektifitas di atas ketinggian $2 \mathrm{~km}$ tidak terlihat. Hal ini kemungkinan disebabkan karena hujan yang sangat deras (terlihat dari reflektivitas di ketinggian $250 \mathrm{~m}$ - $1000 \mathrm{~m}$ yang cukup tinggi) menyebabkan atenuasi yang tinggi, sehingga MRR yang menggunakan frekuensi $24 \mathrm{GHz}$ ini tidak dapat mendeteksi butir hujan yang berada di level atasnya. Kondisi yang sama juga terlihat pada kecepatan jatuh pada gambar 4 (bawah), sehingga metode Williams (1995) untuk menentukan jenis awan hujan tidak dapat diterapkan pada kondisi hujan deras dengan menggunakan data MRR. Metode ini mengharuskan memiliki profil reflektivitas dan kecepatan jatuh sampai ketinggian di atas freezing level untuk mendeteksi keberadaan bright band.

Setelah pukul 7.50 - 8.15 intensitas hujan mulai melemah, dan nilai reflektivitas di level bawah terlihat tidak terlalu tinggi. Pada saat tersebut, MRR sudah dapat mengamati hujan di level atas, sehingga nilai reflektivitas dan kecepatan jatuh dapat teramati sampai ketinggian $5 \mathrm{~km}$. Walaupun tidak terlihat adanya brightband, yang digambarkan dengan nilai reflektifitas yang kuat di sekitar freezing level, tapi karena terlihat adanya perubahan kecepatan yang cukup besar di ketinggian antara 4 - $4.5 \mathrm{~km}$, pada periode ini awan hujan sudah berubah menjadi awan jenis stratiform. Ini merupakan fase dimana awan konvektif mulai berangsurangsur hilang (disipasi).

Dari pengamatan dengan radiometer pada rentang waktu yang sama terlihat bahwa parameter-parameter cuaca yang terukur juga mendukung hasil pengamatan dari MRR. Gambar 5 adalah hasil pengamatan dari masingmasing sensor untuk temperatur permukaan, $\mathrm{RH}$ permukaan, suhu dasar awan dan hujan permukaan. Sensor hujan hanya menunjukkan ada atau tidaknya hujan di permukaan.

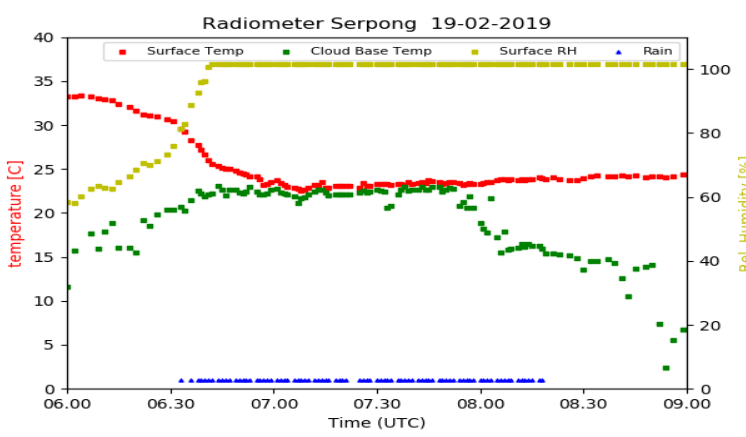

Gambar 5. Pengamatan parameter cuaca dengan sensor permukaan pada radiometer tanggal 19 Februari 2019, yaitu temperatur permukaan (dot merah), kelembapan relatif permukaan (dot kuning), suhu dasar awan (dot hijau) dan hujan permukaan (segitiga biru).
Pada bagian bawah dari gambar 5 , terlihat bahwa hujan terdeteksi sejak sekitar pukul 06.3008.15 (segitiga biru). Kelembapan relatif permukaan (dot kuning) terlihat berangsurangsur naik sejak pukul 06.00 dari $20 \%$ menjadi $100 \%$ pada pukul 06.40 , yaitu pada saat hujan deras di permukaan terdeteksi oleh disdrometer. Bersamaan dengan naiknya $\mathrm{RH}$ permukaan, terjadi penurunan temperatur permukaan dari $34^{\circ} \mathrm{C}$ pada pukul 06.00 yang kemudian berangsur-angsur turun sampai $23^{\circ} \mathrm{C}$ pada pukul 07.00 dan terus stabil sampai hujan selesai (dot merah).

Pada saat sensor hujan mendeteksi adanya hujan, terlihat bahwa suhu dasar awan (dot hijau) mendekati temperatur permukaan, yaitu sekitar $22^{\circ} \mathrm{C}$. Pada saat sebelum hujan dan setelah hujan atau hujan dengan intensitas rendah, nilai suhu dasar awan berfluktuasi antara $15-20^{\circ} \mathrm{C}$. Suhu dasar awan terlihat naik dari 17 ${ }^{\circ} \mathrm{C}$ pada pukul 06.15 dan mencapai $20{ }^{\circ} \mathrm{C}$ pada saat sebelum terdeteksi adanya hujan di pemukaan, yaitu sekitar pukul 06.45. Kondisi ini sesuai dengan keberadaan reflektivitas pada ketinggian 2-4 $\mathrm{km}$ pada pengamatan dengan MRR. Sedangkan pada tahap disipasi, terlihat suhu dasar awan berangsur-angsur turun, yang menandakan bahwa dasar awan makin naik.

Gabungan pengukuran profil temperatur dari radiometer dengan suhu dasar awan dapat menunjukan tinggi dasar awan pada saat itu. Gambar 6 adalah tinggi dasar awan untuk kejadian hujan tanggal 19 Februari 2019. Terlihat pada gambar tersebut bahwa dasar awan mulai terlihat agak rendah sejak pukul 06.00 hingga sesaat sebelum hujan deras pada pukul 06.45. Pada saat intensitas hujan mulai berkurang, yaitu tahap awan konvektif mulai melemah, tampak dasar awan juga mulai naik, dan semakin tinggi setelah 08.45 .

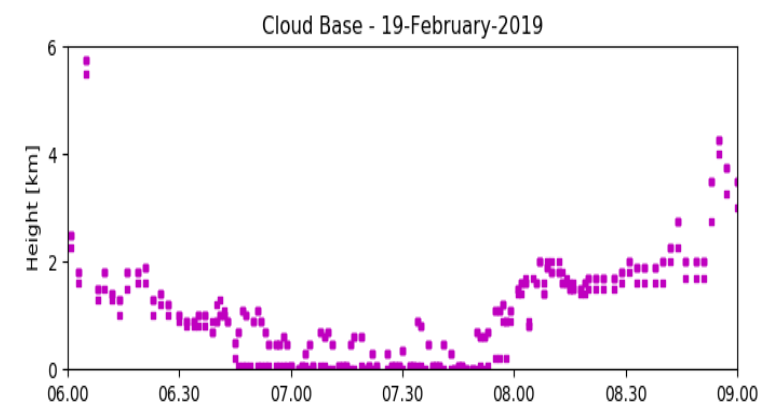

Gambar 6. Tinggi dasar awan yang diukur oleh IRT dan profil temperatur dari radiometer tanggal 19 Februari 2019

\subsubsection{Kejadian Hujan tanggal 9 Januari 2019}

Kejadian hujan pada tanggal 9 Januari 2019 juga mempunyai intensitas hujan yang cukup tinggi. Total akumulasi hujan yang berlangsung selama 6 jam itu mencapai $86 \mathrm{~mm}$, namun curah hujan yang tinggi hanya 
berlangsung selama 30 menit pertama dengan total curah hujan sekitar $85 \mathrm{~mm}$, selebihnya hanya hujan dengan intensitas rendah (gambar 7-bawah). Hujan dengan intensitas tinggi ini merupakan hujan dari awan konvektif, dan selebihnya merupakan hujan stratiform.

Struktur vertikal dari awan hujan dapat dilihat pada gambar 7 (atas). Namun seperti yang telah diterangkan sebelumnya, bahwa untuk hujan dengan intensitas sangat tinggi, MRR tidak dapat mengukur parameter hujan sampai ke lapisan atas. Akan tetapi setelah pukul 22.00 terlihat kemunculan brightband dengan jelas yang berupa reflektivitas yang tinggi pada ketinggian $4.5 \mathrm{~km}$. Kemunculan brightband itu disertai juga dengan adanya perubahan kecepatan secara drastis pada ketinggian di atas $4 \mathrm{~km}$. Hujan stratiform biasanya mempunyai curah hujan yang rendah.
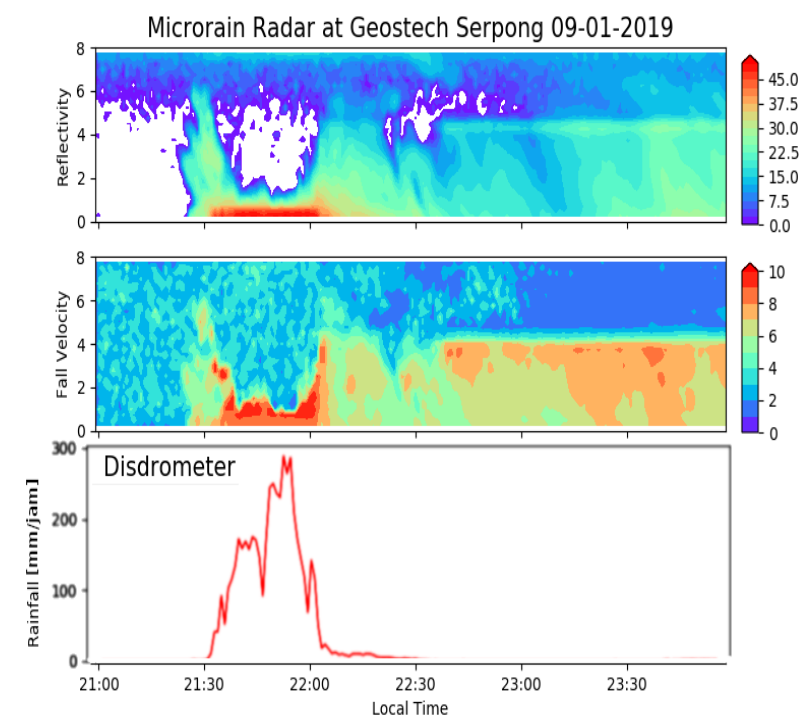

Gambar 7. Pengamatan dengan MRR untuk Reflektivitas (atas) dan Kecepatan jatuh butir hujan (tengah), juga pengamatan curah hujan dengan disdrometer (bawah) pada kejadian hujan tanggal 9 Januari 2019.

Dari pengamatan dengan sensor hujan pada radiosonde, hujan terdeteksi sejak 21.35 sampai baru terlihat hilang 4 jam kemudian (gambar 8). Sebelum 21.15 ketinggian awan tampak sangat berfluktuasi, kemungkinan pada saat tersebut belum ada awan yang cukup besar. Pada pukul 21.15 - 21.30 tampak ketinggian awan sekitar $1 \mathrm{~km}$, setelah itu hujan deras sampai pukul 22.10. Antara pukul 22.10 - 22.40, masih terdeteksi hujan oleh penakar manual, dan jika melihat struktur vertikal dari hujan ini nampak bahwa di atas freezing level masih terlihat adanya reflektivitas, dan juga ada downdraft. Kondisi seperti ini dapat diklasifikasikan sebagai transisi dari konvektif ke stratiform.

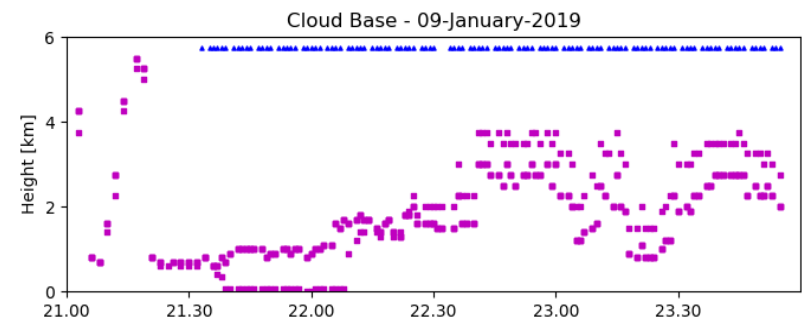

Gambar 8. Pengamatan tinggi dasar awan dengan IRT (dot magenta) dan sensor deteksi hujan permukaan (segitiga biru).

Ketinggian dasar awan terukur oleh radiometer sekitar $2 \mathrm{~km}$. Setelah pukul 22.40 sampai hujan selesai kondisinya terlihat seperti hujan dari awan stratiform. Ketinggian dasar awan yang terpantau bervariasi, sampai mencapai $4 \mathrm{~km}$.

\subsection{Variasi Harian Tinggi Dasar Awan}

Pengamatan panjang selama musim hujan di Serpong diperoleh informasi tinggi dasar awan. Walaupun IRT yang terpasang pada radiosonde hanya dapat mengukur suhu dasar awan tepat di atasnya, namun dapat mewakili kondisi di wilayah tersebut. Gambar 9 merupakan distribusi tinggi dasar awan selama masing-masing bulan. Banyaknya data pada masing-masing bulan dihitung berdasarkan data mentah yang mempunyai kerapatan 3 menit. Pada bulan Januari (gambar 9.a) terlihat distribusinya hampir merata, hanya sedikit terlihat kemunculan awan di ketinggian $4 \mathrm{~km}$ antara pukul 15.00-21.00 UTC (22.00-04.00 WIB). Untuk bulan Februari (gambar 9.b), terlihat awan pada ketinggian $2 \mathrm{~km}$ muncul sekitar pukul 06.00-09.00 UTC (13.0016.00 WIB) dan 15.00-17.00 UTC (22.00-24.00 WIB), sedangkan yang muncul pada ketinggian 4 $\mathrm{km}$ terlihat pada malam hari (21.00-01.00 WIB). Bulan Maret (gambar 9.c) terlihat lebih banyak kemunculan awan. Hampir sepanjang waktu, awan dengan ketinggian dasar awan antara 3.0$4.5 \mathrm{~km}$ terlihat pada bulan ini. Awan dengan tinggi dasar awan sekitar $1 \mathrm{~km}$ hanya terlihat pada siang hari, yaitu pukul 03.00-10.00 UTC (10.00-17.00 WIB).

Jumlah dasar awan yang muncul untuk masing-masing bulan terhadap ketinggiannya dapat dilihat pada gambar 10. Terlihat pada gambar ini bahwa pada bulan Januari (garis merah) tinggi dasar awan tersebar antara 1.5-4.5 $\mathrm{km}$ dengan maksimum terbanyak pada ketinggian $4.25 \mathrm{~km}$ dengan jumlah 2355 kali. Sedangkan bulan Februari (garis kuning) mempunyai puncak di ketinggian $1 \mathrm{~km}$ dengan jumlah 2899 kali. Bulan Maret (garis hijau) mempunyai dua puncak, yaitu di ketinggian $1 \mathrm{~km}$ dan $3.25 \mathrm{~km}$, dengan jumlah masing-masing adalah 2651 dan 3953 kali. 
(a) JAN 2019

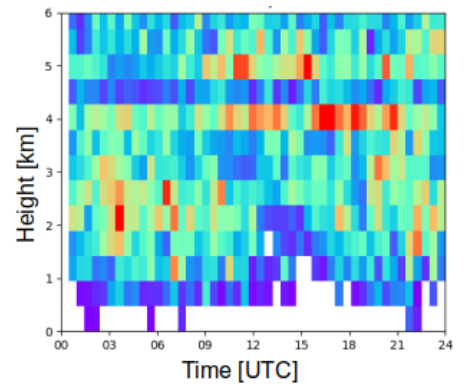

(b) FEB 2019

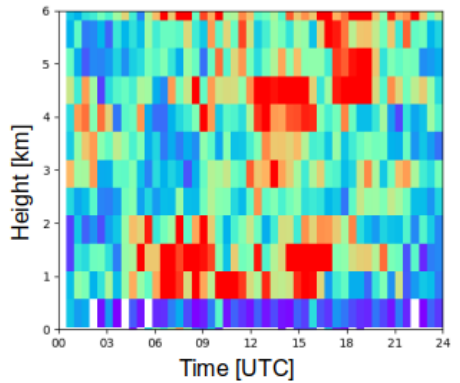

(c) MAR 2019

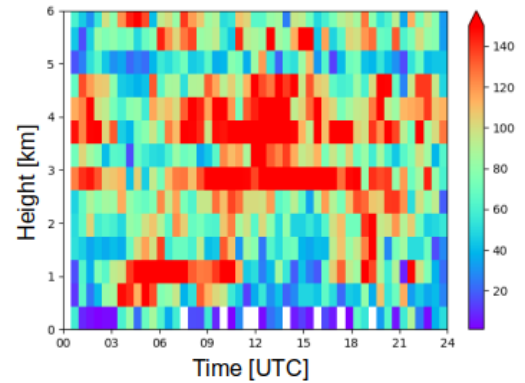

Gambar 9. Variasi harian tinggi dasar awan untuk bulan Januari (a), Februari (b), dan Maret 2019 (c).

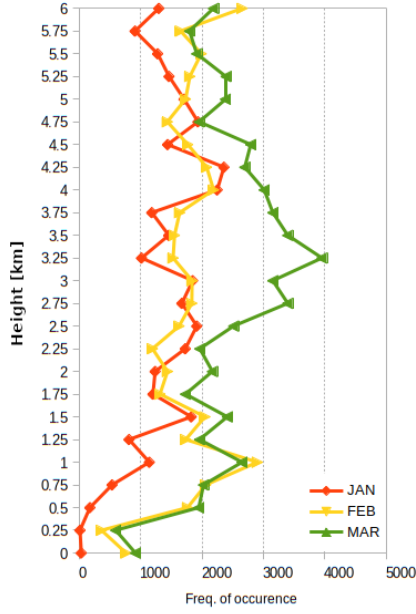

Gambar 10. Profil frekuensi kemunculan tinggi dasar awan untuk bulan Januari (merah), Februari (kuning) dan Maret (hijau) 2019.

\section{KESIMPULAN}

Pengamatan tinggi dasar awan di Serpong dilakukan dengan menggunakan Infra Red Thermometer (IRT) sensor yang terpasang di radiometer. Perbandingan dengan hasil pengukuran MRR yang mempunyai kemampuan melihat struktur vertikal awan digunakan untuk mengetahui jenis awannya. Data hujan dari disdrometer yang terpasang di lokasi yang sama juga digunakan untuk menentukan kejadian hujan. Dua contoh kejadian hujan yang cukup tinggi selama 3 bulan pengamatan (JanuariMaret 2019) dapat mewakili kejadian hujan dari awan konvektif dan awan stratiform.

Hasil penelitian menunjukkan bahwa data ketinggian dasar awan yang diperoleh dari pengukuran dengan IRT radiometer menunjukkan kecocokan dengan kemunculan awannya. Pada saat sebelum dan setelah terjadi hujan deras, IRT dapat mengukur tinggi dasar awan yang muncul. Demikian pula pada saat hujan stratiform, yang mempunyai awan dengan tinggi sekitar $2 \mathrm{~km}$ terpantau dengan baik.

Variasi harian menunjukkan pada pukul 22.00-03.00 WIB banyak awan dengan dasar awan sekitar 4.0-4.5 km, sedangkan pada bulan Februari dan Maret banyak awan yang muncul siang hari (10.00-17.00 WIB) mempunyai dasar awan sekitar 1.0-2.0 km.
Penelitian ini masih harus dikembangkan dengan melakukan pengukuran menggunakan ceilometer atau lidar agar nilai tinggi dasar awan dapat diukur dengan lebih tepat lagi.

\section{DAFTAR PUSTAKA}

Athoillah, I., Dewi, S., Renggono, F. (2016). Perbandingan Pengukuran Radiometer dan Radiosonde pada Musim Hujan di Dramaga Bogor. Jurnal Sains \& Teknologi Modifikasi Cuaca, 17(2), 75-82. doi: 10.29122/jstmc.v17i2.640

Craven, J.P., Jewell, R.E., Brooks, H.E. (2002) Comparison between Observed Convective Cloud-Base Heights and Lifting Condensation Level for Two Different Lifted Parcels. Weather and Forecasting, 17(4), 885-890. doi: 10.1175/15200434(2002)017<0885:CBOCCB>2.0.CO;2

Forsythe, J.M., Haar, T.H.V., Reinke, D.L. (2000) Cloud-Base Height Estimates Using a Combination of Meteorological Satellite Imagery and Surface Reports. Journal of Applied Meteorology, 39(12), 2336-2347. doi: $10.1175 / 1520-$ 0450(2000)039<2336:CBHEUA>2.0.CO;2

Mims III, F.M., Chambers, L.H., Brooks, D.R. (2011) Measuring Total Column Water Vapor by Pointing an Infrared Thermometer at the Sky. Bulletin of the American Meteorological Society, 92(10),1311-1320.

doi: 10.1175/2011BAMS3215.1

Peters, G., Fischer, B., Andersson, T. (2002). Rain Observations with a Vertically Looking Micro Rain Radar (MRR). Boreal Environment Research, 7(4), 353-362.

Renggono, F. (2017). Variasi Harian dan Tahunan Hujan di Serpong Berdasarkan Pengamatan dengan Micro Rain Radar. Jurnal Sains \& Teknologi Modifikasi Cuaca, 18(2), 75-80. doi: 10.29122/jstmc.v18i2.2785

Stackpole, J.D. (1967). Numerical Analysis of Atmospheric Soundings. Journal of Applied Meteorology, 6(3), 464-467. doi: 101175/15200450(1967)006<0464:NAOAS>2.0.CO;2 
Syaifullah, M.D. (2014) Validasi Data TRMM terhadap Data Curah Hujan Aktual di Tiga DAS di Indonesia. Jurnal Meteorologi dan Geofisika, 15(2), 109-118. doi: 10.31172/jmg.v15i2.180

Wang, Z., Wang, Z., Cao, X., Mao, J., Tao, F., Hu, S. (2018) Cloud-Base Height Derived from a Ground-Based Infrared Sensor and a Comparison with a Collocated Cloud Radar. Journal of Atmospheric and Oceanic Technology, 35(4), 689-704. doi: 10.1175/JTECH-D-17-0107.1
Williams, C.R., Ecklund, W.L., Gage, K.S. (1995) Classification of Precipitating Clouds in the Tropics Using 915-MHz Wind Profiler. Journal of Atmospheric and Oceanic Technology, 12(5), 996-1012. doi: 10.1175/15200426(1995)012<0996:COPCIT>2.0.CO;2

Yang, H-Y., Chang, K-H., Kang, S-T. (2013). Combined Microwave Radiometer and Micro Rain Radar for Analysis of Cloud Liquid Water. Journal of the Chosun Natural Science, 6(1), 12-15. doi: 10.13160/ricns.2013.6.1.012 